\title{
5 \\ The Chronology of Batanes Prehistory
}

\author{
Peter Bellwood and Eusebio Dizon
}

This chapter describes the radiocarbon dated chronology of all the sites excavated in the Batanes Islands, and groups the assemblages into four dated phases that cover the past 4000 years. The major sites excavated between 2002 antd 2007, on Itbayat, Siayan, Batan and Sabtang Islands, have been described in the previous three chapters. Here, it is necessary to consider absolute chronology as derived from $\mathrm{C} 14$ dates, to place each site in relative chronological order with respect to other sites, and to consider the issue of phases within Batanes prehistory. The latter are a little difficult to distinguish since most of Batanes prehistory was essentially "Neolithic", despite the rare presence of metal in some younger sites. The only stratigraphic boundary of a catastrophic kind was produced by the eruption of Iraya on Batan Island at about 1500 years ago, but the geomorphic results of this eruption are only visible in central Batan Island. It is clear, however, that Batanes prehistory witnessed some significant changes in pottery shape and decoration through its 4000 years of progression, and the same appears to be true for other artefacts of stone and shell, as well as for the presences of imported Taiwan nephrite and slate.

Do we need phases for Batanes prehistory? Bellwood and Dizon (2005) decided to avoid putting firm chronological boundaries on the cultural phases suggested earlier in the life of the project (Bellwood et al. 2003) owing to problems of overlap and dating uncertainty. Furthermore, there is absolutely no reason to suppose that the whole population of the Batanes Islands was ever replaced at any time in prehistory, even after the Iraya eruption. One basic problem is that, as more sites are discovered, excavated and dated, so one phase tends to blend into another. Eventually, their apparent signatures tend to disappear into a hazy background, although it can still remain the case that specific artefact categories have specific time ranges (see Fig. 5.3).

To circumvent this problem of overlap one might ignore phases altogether and just discuss each site as a completely independent entity. But the time always comes when a coherent presentation of Batanes prehistory is required, by general public and other scholars alike, that needs to be more than just a list of sites, assemblages and dates. Somewhere along the line, one has to attempt to write some coherent history for interested parties who are not archaeologists (e.g. the Batanes people themselves).

When our research began on Batan Island in 2002, it was fairly evident that three separate assemblages were present on this island, at least in terms of pottery. These were termed the Sunget Phase with its circle-stamped pottery dated 1200 to 700 BC, then the Naidi Phase with its plain and red-slipped pottery between $700 \mathrm{BC}$ and $\mathrm{AD}$ 500, and finally the Rakwaydi Phase with its mainly plain and unslipped pottery postdating the AD 500 Iraya eruption (Bellwood et al. 2003:151). The Sabtang research produced a sequence matched most closely in Batan. But 
further work on Itbayat soon complicated matters, and it became necessary on this island to identify the Torongan, Anaro and Garayao phases, with the first-named having plain red-slipped pottery that predated the Sunget phase on Batan. Indeed, it soon became apparent that four panBatanes pottery phases were being foreshadowed in terms of typology. The first (Torongan) had plain red-slipped pottery, the second (Sunget and early Anaro) had circle-stamped pottery, the third (Naidi and later Anaro) saw a return to plain red-slipped pottery, and the fourth (Rakwaydi and Garayao) was focused on plain and mostly unslipped pottery.

By the end of the fieldwork in 2007, it was possible to characterise these four successive phases as follows, based on the distributions of pottery characteristics in all of the excavated sites, on all investigated islands, and considering regional trends further afield in southeastern Taiwan and in the Cagayan Valley of northern Luzon:

Phase 1: red-slipped plain wares: Torongan and Reranum caves on Itbayat only, with an added (and unique for Batanes) presence of fine cord-marked pottery in Reranum.

Phase 2: circle-stamped decorative patterns imposed over continuing red slip: Sunget (Batan), Anaro (Itbayat) and Savidug (Sabtang). Within Anaro there are two apparent sub phases, with older rectilinear and younger lozenge (net-like) emphases in the designs (described in chapter 6).

Phase 3: plain wares with continuing red slip, but no stamping: Naidi and Payaman (Batan), Mitangeb (Siayan), upper layer 4 at Savidug, and the middle layers at Anaro. This phase has shorter but cross-sectionally more complex rim forms than Phases 1 and 2, especially thickened rims.

Phase 4: similar to Phase 3, but with the appearance of imported Asian glazed ceramics in small quantities, grading upwards into the European contact phase. There seems little point in giving Phase 4 a precise termination date, although one could choose the late $17^{\text {th }}$ century, when the first recorded observations of Batanes society were made.

The marker horizon represented by the AD 500 eruption of Mt Iraya on Batan is, of course, stratigraphically useful for correlation purposes. It does not in itself mark a phase boundary since there was no obvious change in artefact styles that occurred precisely around AD 500. However, by examining the date distributions for the Batan Island sites plotted in the two right hand columns in Fig. 5.1, it can be seen post-eruption occupation in central Batan, at least in terms of the available C14 dates, could have witnessed a hiatus to some degree between AD 500 and 1000. All of the C14 means from the pre-eruption occupations at Naidi, Payaman, Tayid and Mahatao predate AD 500, and one Payaman date (ANU 12086 - 1486 uncal. BP) corresponds virtually exactly with the presumed date of the eruption. Reoccupation, in the Mavuyok, Mavatoy and Dios Dipun rock shelters, did not apparently occur until after AD 1000.

We need now to give date ranges to these four phases defined by artefact changes, an exercise for which the raw data are given in Table 5.1. The 51 radiocarbon dates listed were produced by the Radiocarbon Laboratory at ANU, the Waikato Laboratory in New Zealand, and the Australian Institute of Nuclear Sciences and Engineering at Lucas Heights in Sydney. It should be remembered that there is absolutely no sign of any preceramic occupation in Batanes; everything found so far is Neolithic or later, despite the excavation of no less than seven separate cave and rockshelter sites (Reranum, Torongan, the Anaro 3 and 6 shelters, Dios Dipun, Mavuyok a Ahchip and Mavatoy). This seems to rule out chance as a major factor in the absence of pre-Neolithic settlement. If there ever was a Batanes Palaeolithic, it has been erased with astonishing efficiency from the landscape.

There is another factor connected with the radiocarbon dates listed in Table 5.1. This is that we have no charcoal dates from the oldest Batanes sites, these being Torongan and Reranum caves on Itbayat. The Batanes environment is generally subject to strong and seasonally-variable weathering conditions, such that ancient charcoal seems generally to have disintegrated and been washed through soil deposits by water movement, especially in the open sites subject to the direct 
impact of heavy monsoonal rainfall. Charcoal sometimes survives under protective covers such as large potsherds or rocks, but large concentrations were very rare in our excavations, except in very recent cave sites such as Mavuyok a Ahchip on Batan. Most of our early radiocarbon dates are from marine shells and food residues attached to sherds. The oldest dated charcoal comes from Savidug Dune Site, at only 2870 radiocarbon years (Wk 21810).

Marine shells require a variable marine reservoir calibration, and food residues can sometimes incorporate ancient carbon residues contained within potting clays, especially if sample removal in the laboratory was not sufficiently careful. We have potential problems here, as discussed by Anderson (2005), who favours extremely young dates for Batanes prehistory based on the limited results of our first two seasons of excavation in 2002 and 2003. In the case of Torongan Cave, however, it can be seen that the food residue and marine shell dates are very similar in range, back to beyond $2000 \mathrm{BC}$, which is reassuring. The marine shells come from a location within the cave that is about 150 metres from the sea, and about $13 \mathrm{~m}$ above sea level (Fig. 2.5). So it is very unlikely that the dated shells were simply washed there by high seas. Movement by hermit crabs is possible, as discussed in chapter 12, but the shells all appear fresh and not heavily rolled, so their role as dating material is not necessarily undermined. The Batanes dates overall, as presented in Table 5.1 and Fig. 5.1, give strong support to the claim that Batanes prehistory had commenced by 2000 BC. Further precision at the moment would be unwarranted.

\section{Batanes Islands Phase 1, outer limits 2500 to $1000 \mathrm{BC}$}

The most significant dates from Torongan and Reranum are illustrated in the two OxCal plots in Fig. 5.2. In Torongan, these all come from the zone of in-washed soil with red-slipped pottery between 40 and $60 \mathrm{~cm}$ in depth, and range from $2500 \mathrm{BC}$ onwards to $1200 \mathrm{BC}$ for two sherd residue and four marine shell samples. Reranum shows obvious disturbance. Sherds of fine cordmarked pottery occur throughout the very shallow deposit (maximum $50 \mathrm{~cm}$ ) and these are very small in size compared to the bulk of the Reranum pottery, thus perhaps derived from an older deposit now destroyed. Such cord-marked pottery has not been reported before from any other site or time period in the northern Philippines (except for one surface-collected sherd from Anaro), although there is cord-marked pottery in the undated Tabon Caves sequence from Palawan (Fox 1970: Fig. 21). The disappearance of fine cord-marked pottery in southeastern Taiwan had occurred by about 2000/1500 BC (Hung 2005, 2008).

\section{Batanes Islands Phase 2, outer limits $1300 \mathrm{BC}$ to $\mathrm{AD} 1$}

The circle-stamped and red-slipped pottery in Batanes progressed through two sub phases, the earlier dominated by rectangular meander designs, the younger dominated by lozenge (fishnet) designs. The fishnet type of decoration is only reported in quantity from the squares with plentiful Fengtian nephrite excavated at Anaro 3 on Itbayat. The earlier pottery with rectangular meanders, also found with Fengtian nephrite but in smaller amounts and without the manufacturing debris associated with circular ear ornaments, is represented at Sunget, in the basal layers at Anaro, and at Savidug. Fig. 5.2 (bottom) shows the five C14 dates most relevant for this early rectangular meander sub phase, all on food residues on sherds, and all clustered between 1300 and $800 \mathrm{BC}$. The two younger dates from Sunget listed in Table 5.1 are considered to reflect post-occupation cultivation, and the very old date for OZH 776 clearly reflects the use of ancient resin for coating pottery.

The younger sub phase, with the lozenge/fishnet patterns, is found only at Anaro 3, where it is associated with the three dates OXJ 692, 693 and 695 (Table 5.1). These suggest a range between $700 \mathrm{BC}$ and $\mathrm{AD} 1$. The younger C14 dates from Anaro 3B, as discussed in more detail in chapter 6, belong to Phase 3 contexts. A clinching factor here is Wk 21971 from the site of Mitangeb on Siayan, which dates to about AD 1, yet is associated with absolutely no stamped pottery at all, and so postdates Phase 2 (see the plotting of these dates in Fig. 5.1). 


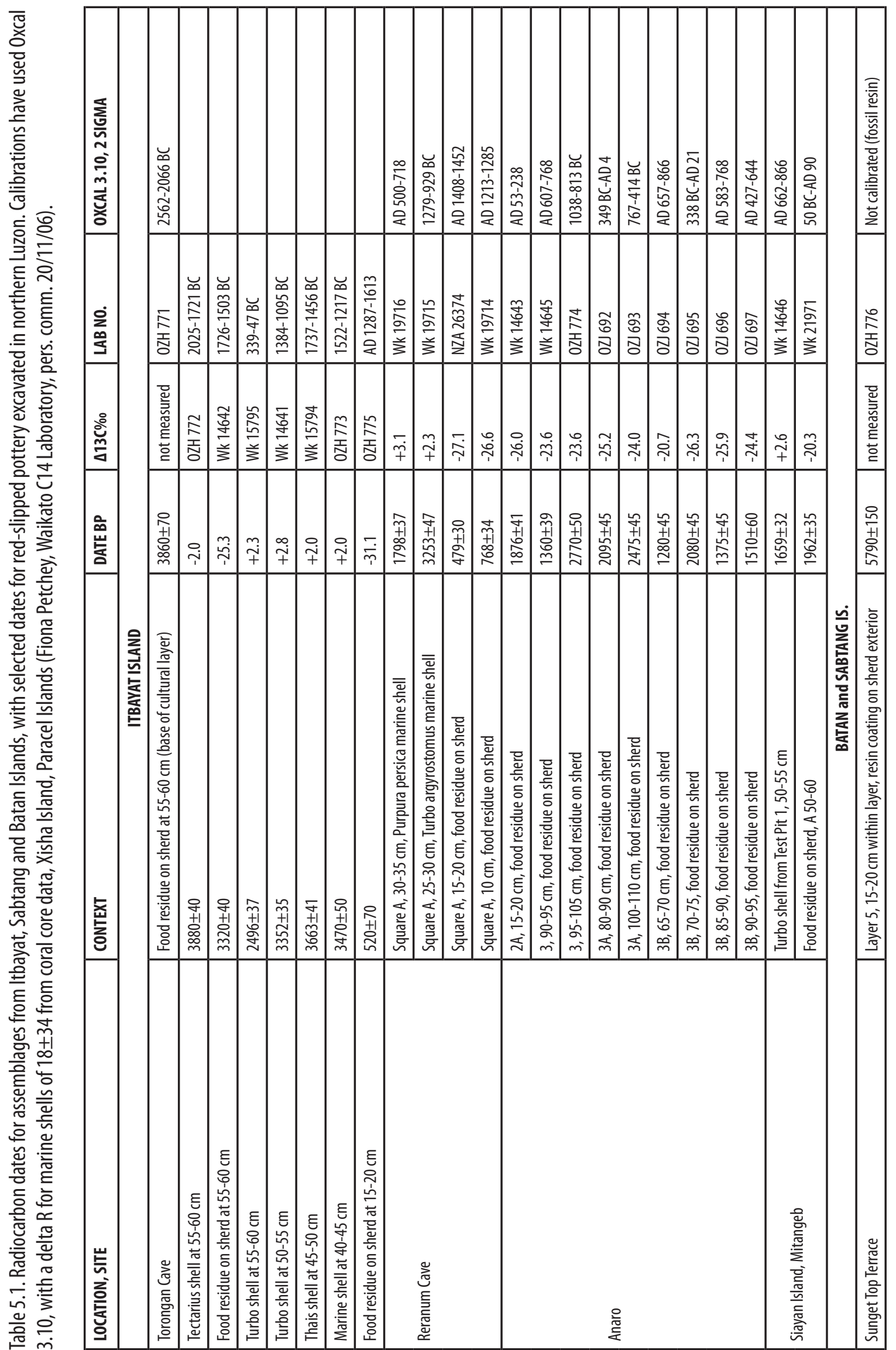




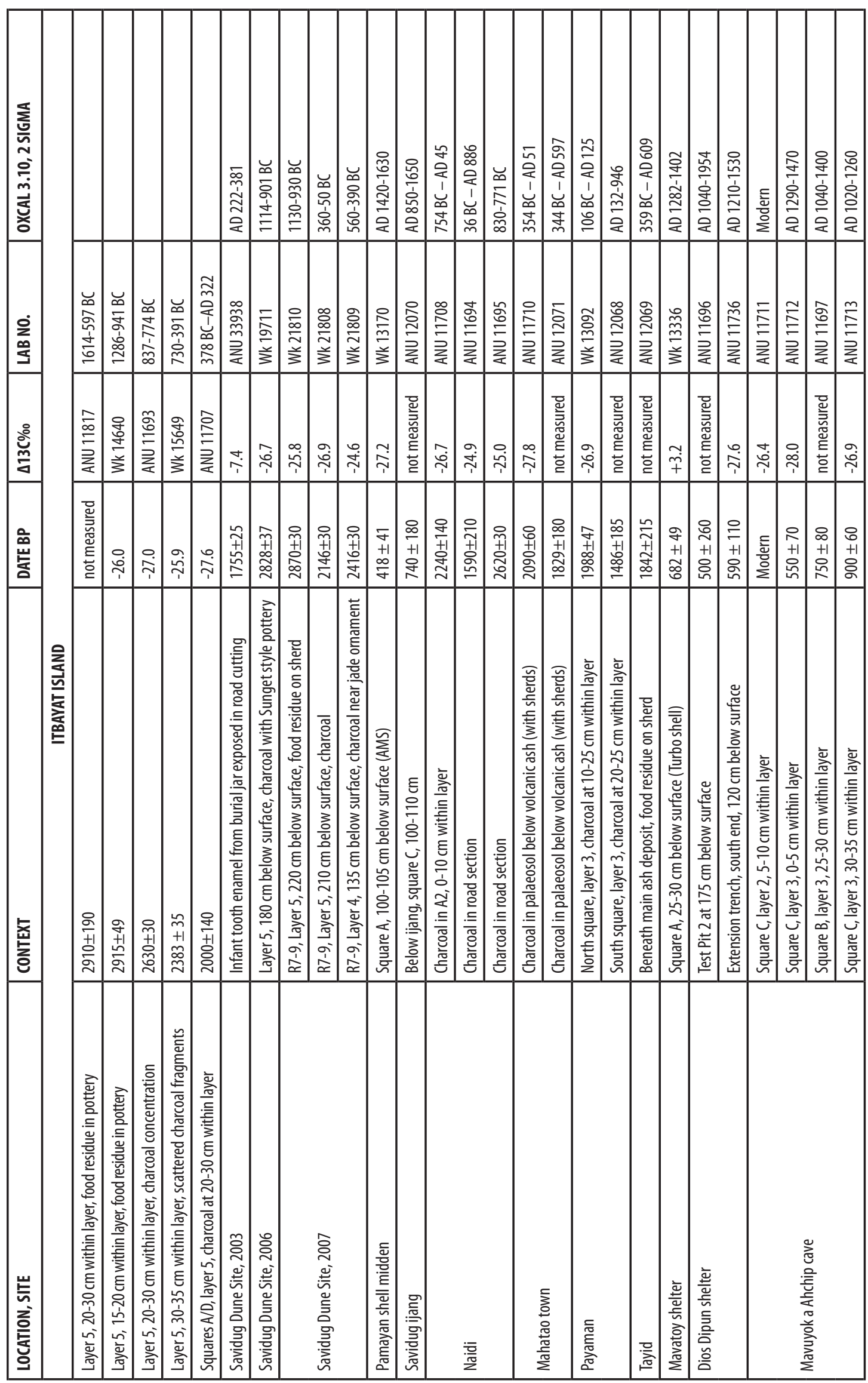




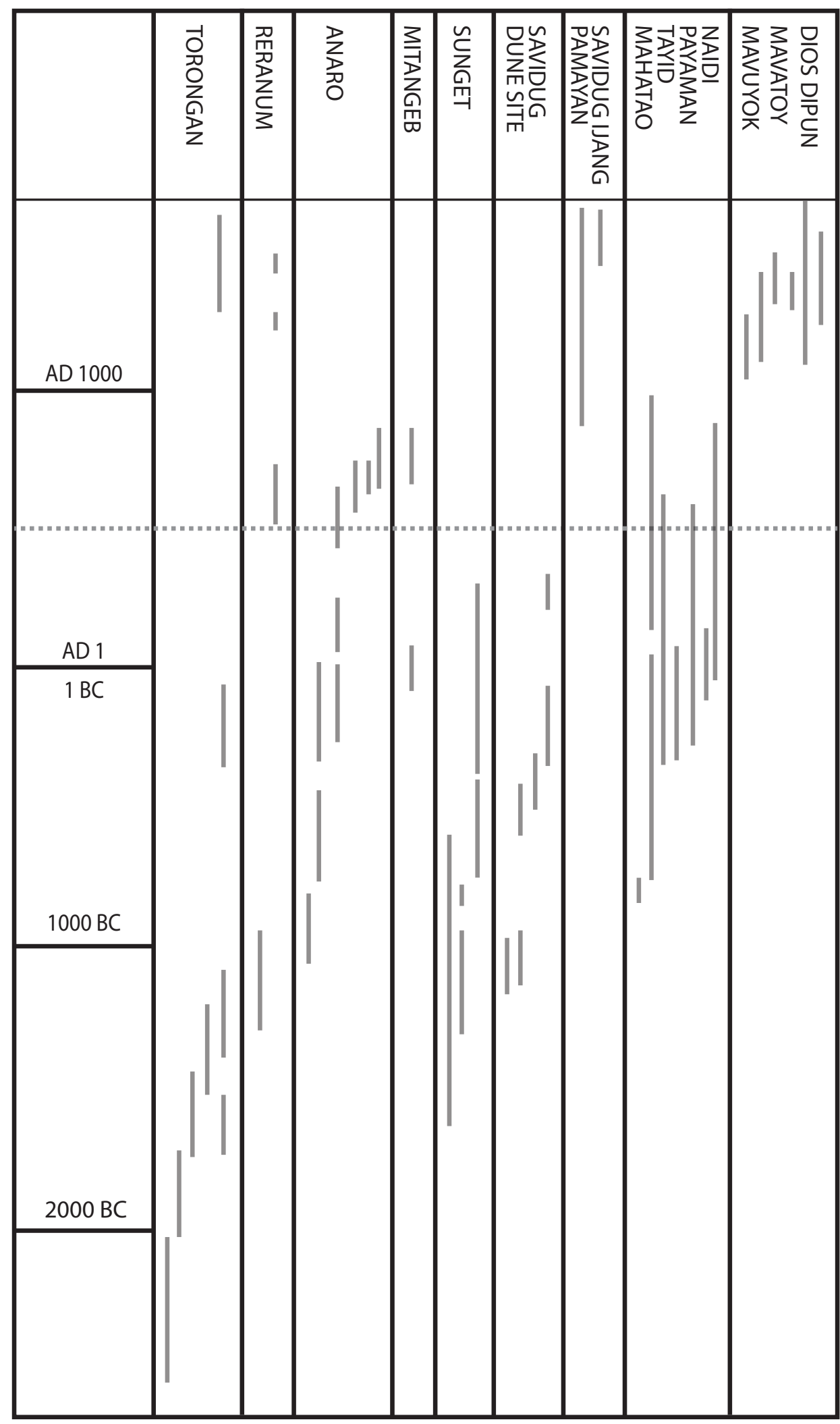

Figure 5.1. A plot of all the Batanes calibrated radiocarbon dates with their ranges, by site, as listed in Table 5.1. The dotted line represents the Iraya eruption.

Source: Peter Bellwood. 

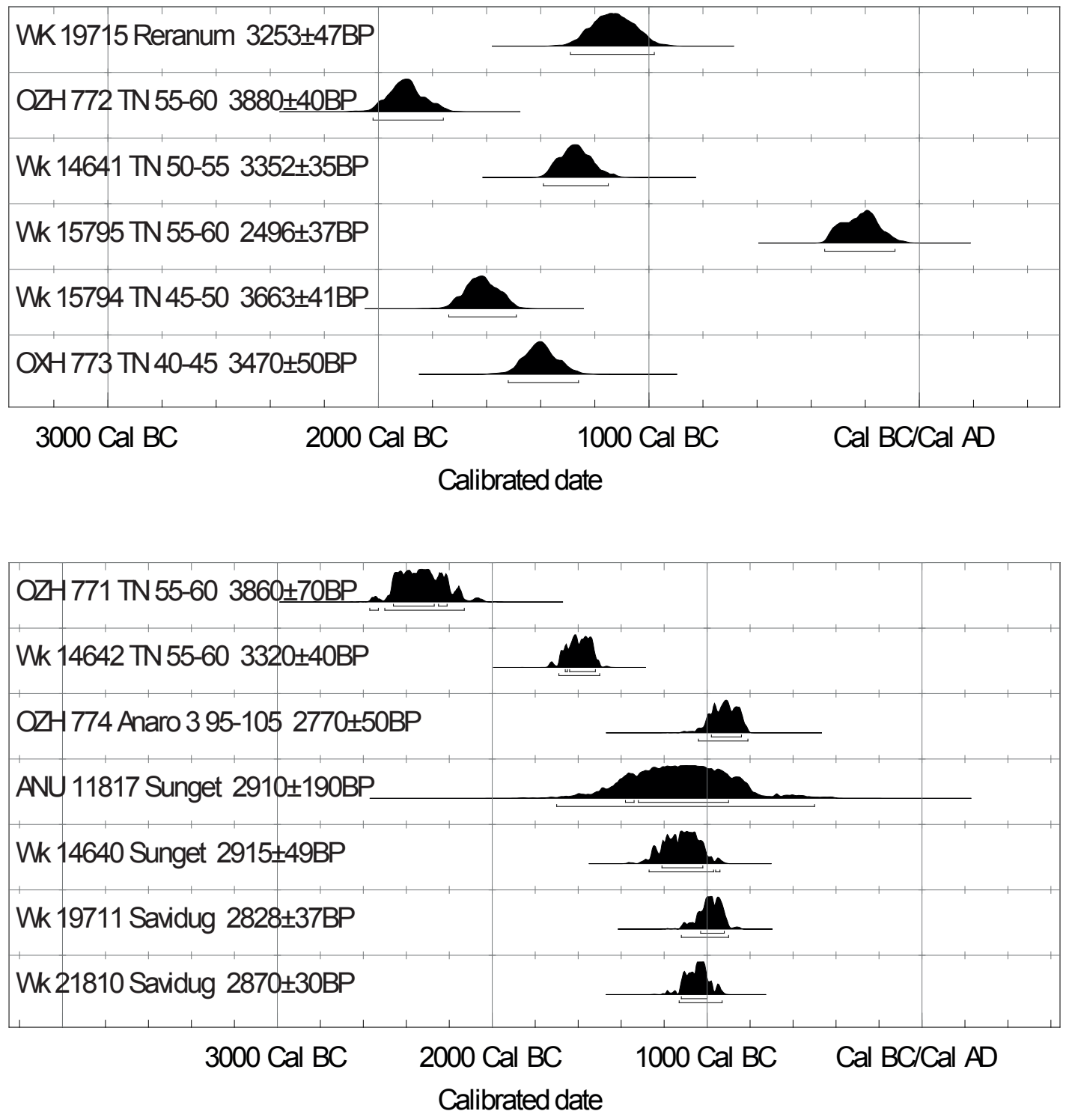

Figure 5.2. Top: Oxcal 3.10 plots of marine shell dates older than 2500 cal. BP (except for Wk 15795) from Reranum and Torongan (TN) Caves. Bottom: 0xcal 3.10 plots of food residue dates older than 2500 cal. BP from Torongan Cave (TN), Anaro 3, Sunget and Savidug Dune Site.

Source: Peter Bellwood.

\section{Batanes Islands Phase 3, outer limits 500 BC/AD 1 to AD 1200}

The upper 30-40 cm in the Anaro 3 squares, the site of Mitangeb on Siayan Island, the upper part of layer 4 at Savidug (with the jar burials), and the sites of Naidi, Payaman, Tayid and Mahatao on Batan belong in this phase, which lacks any pottery surface decoration apart from red-slipping. The Naidi dates from Batan are the oldest, potentially back to 800 BC (ANU 11695), but the sample from this site is so small that an absence of stamped pottery cannot be guaranteed. The Naidi pottery is very similar to that from Payaman in terms of rim shapes, and Payaman, like Naidi, lacks stamped pottery. Payaman dates from about AD 1 onwards (Wk 13092 in Table 
5.1). The Mitangeb date $\mathrm{Wk} 21971$, also $c$.AD 1, is significant because of the complete lack of any stamping in such a large sample, suggesting its true demise by this time. Additional dates for this phase come from Mahatao and Tayid.

\section{Batanes Islands Phase 4, commencement $c . A D 1200$}

This phase is marked by the appearance of imported ceramics, that are represented through excavation in layer 2 at Savidug and at Pamayan, both on Sabtang Island, although lots of recent sites with imported ceramics on Batan are reported in Koomoto 1983. As discussed in chapter 6, the ceramics found in the upper layer at Savidug are of monochrome types that many reports loosely categorise as "Song and Yuan", on the assumption that blue and white sherds denote the following Ming or Qing dynasties. The Batan Island cave sites of Dios Dipun, Mavuyok a Ahchip and Mavatoy also date to within the past millennium, but lack imported ceramics.

\section{Further comments on chronology}

One difficulty with attempting to establish a chronological sequence for the whole of the Batanes is that different islands might have had different sequences of changing pottery and artefact styles, although their geographical closeness and inter-visibility render absolute isolation and independence unthinkable. It is interesting, however, that cord-marked pottery has only so far been found in Reranum shelter, and lozenge shaped circle-stamped motifs only in Anaro, both on Itbayat. This raises the possibility that what might appear to be a continuous sequence of change is in fact made up of a large number of short term occupations revealed to us by those locations selected for excavation. Many times and places were not, of course, investigated by excavation at all, hence perhaps some of the apparent "gaps" and C14 ambiguities in the overall sequence.

Nevertheless, examination of the plot of $\mathrm{C} 14$ dates in Fig. 5.1 reveals that there was no obvious hiatus of non-occupation across the Batanes at any time in prehistory, despite the likelihood of an abandonment of parts of Batan after AD 500. Nothing in the record suggests a total population replacement at any time, and nothing refutes the suggestion that, in the Batanes Islands in general, the first arrivals at $2000 \mathrm{BC}$ were at least partial ancestors for the inhabitants in AD 1687.

It is worth noting also that the general sequence proposed here, despite the gaps, matches well with pottery sequences published from Taiwan, northern Luzon, and even areas further south such as Sabah and eastern Indonesia (Bellwood 1988, 2007; Anggraeni et al. in press). Plain red-slipped pottery seems to predate stamped and incised pottery very widely in eastern Island Southeast Asia, and the latter often reverts to plain ware at some point during the Early Metal Phase. A possible exception to this generalisation could be the Cagayan valley on Luzon (Hung et al. 2011; Carson et al. 2013), where the punctate stamped pottery appears to be at the base of the sequence, although this is still a little uncertain.

Fig. 5.3 illustrates the four proposed phases for Batanes, together with likely chronologies for the excavated and C14-dated Batanes sites, and contemporary cultural manifestations in Taiwan and Luzon (see Bellwood 2011; Bellwood et al. 2011 for further discussion). 


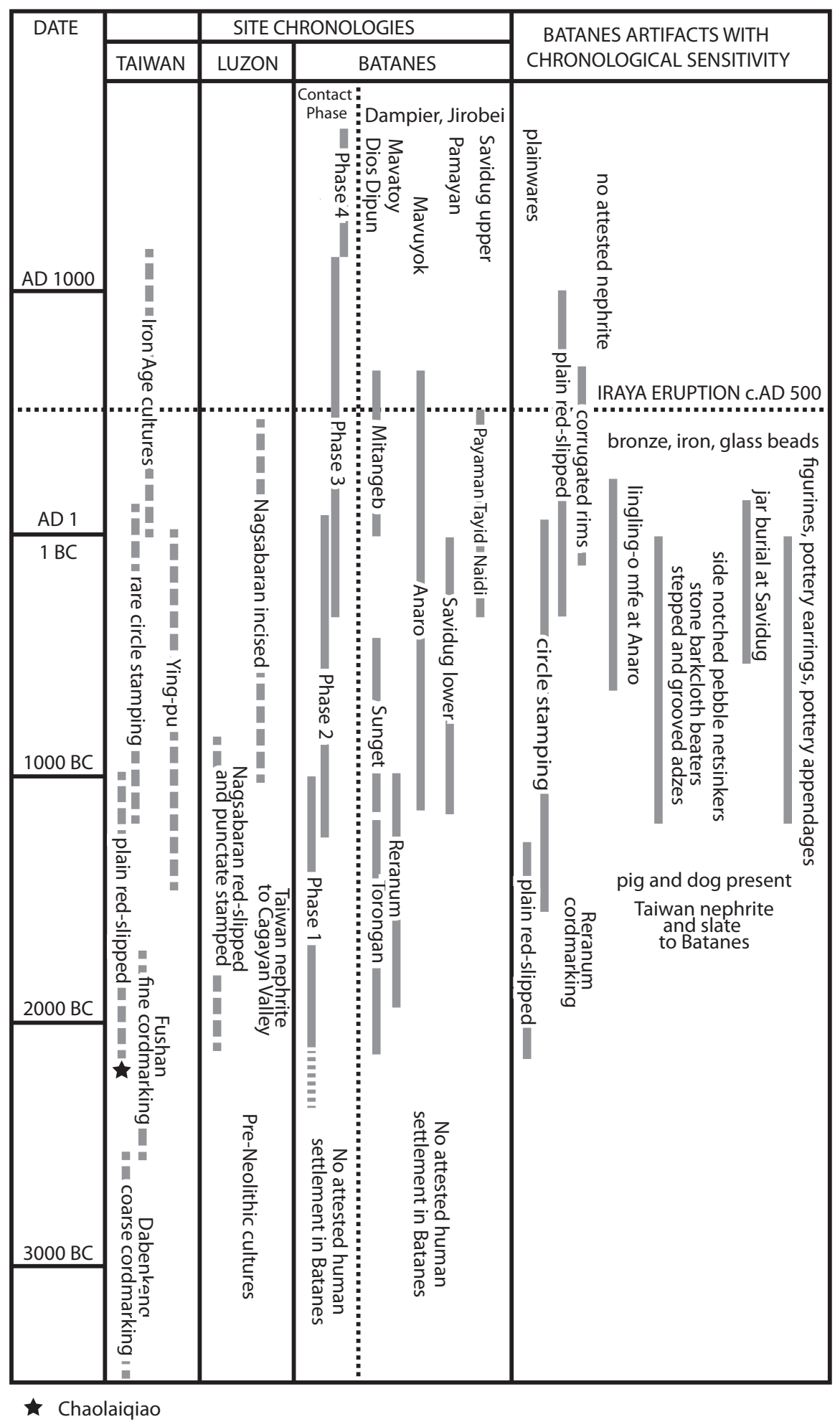

Figure 5.3. The four proposed phases for Batanes prehistory (4th column from left), together with radiocarbon chronologies for the excavated Batanes sites, and contemporary cultural manifestations in Taiwan and Luzon. This figure is repeated later as Fig. 13.1.

Source: Peter Bellwood. 